\title{
Katar'da Osmanlı Hâkimiyetine Tarihsel Bir Bakış
}

\author{
Dummar Bingöl* \\ (ORCID ID: 0000-0002-8686-7929) \\ Makale Gönderim Tarihi \\ 01.03.2019 \\ Makale Kabul Tarihi \\ 15.03.2019
}

\section{Özet}

Bu çalışmada temel olarak Yavuz Sultan Selim'in Mısır seferiyle Katar'ın Osmanlı himayesine girmesinden 1915 yılında son askerimizin Katar'dan çıkmasına kadar geçen süreyi irdeledik. Osmanlı'nın bu bölgede Portekizlilerle daha sonra uzun bir süre İngilizlerle mücadele ettiği görülür. 1971 yılında Şeyh Casim'in Osmanlının Basra valisi Mithat Paşa'yı Katar'a davet etmesiyle ilk defa bölgeye Osmanlı ordusu yerleşir. Bu dönemden sonra Osmanlı Devleti Katar'a egemenliğini kurmak için mücadele edecektir. Bunun yanında Osmanlı Devleti bölgedeki hâkimiyetini sağlamlaştırmak için mevcut kabilelerden Al Sani ailesinden Şeyh Casim'i bölgeye kaymakam olarak atar. Şeyh Casim Osmanlı Devletinin bölgedeki hâkimiyetini artırmak için Katar'daki kabilelerle, komşu kabilelerle, Beni Suud'la ve İngilizlerle uzun süre mücadele edecektir. Bu mücadeleleri sırasında bölgede mevcut Osmanlı birlikleri ve idarecilerle zaman zaman karşı karşıya geldiği de görülmüştür.

Osmanlı Devleti bölgenin önemini bildiği için burayla özel ilgilendiği 1888 ve 1901 de bölgeye memurlarını göndererek ıslah ve reform çalışmaları raporladığı Osmanlı vesikalarında görülmektedir. Ancak bu reform çalışmaların bir kısmı gerçekleştirilirken büyük bir kısmı Osmanlı Devletinin coğrafyasında yaşadığı sıkıntılardan dolayı gerçekleştirememiştir. 1894'te gelindiğinde Şeyh Casim Al Sani'ye İngiliz baskılarının arttığını ve onlarla mücadele edebilmek için çok fazla çaba gösterdiği görülmektedir. Ingilizlerin Zubara ve Adid bölgeleri için Bahreyn adına hak iddia etmeleri bu bölgelerdeki mücadeleleri arttıracaktır. Uzun süre bölgede mücadele vermek zorunda kalan Şeyh Casim Al Sani sonunda Osmanlı Devletinin desteğiyle amacına ulaşarak kendi kabilelerini bölgeye yerleştirmeyi başarır.

1910 - 1913 yıllarında Osmanlılar ve İngilizler arasında bölge için müzakereler yapılacak Osmanlı Devletinin Balkan Savaşlarını fırsat bilen İngiltere Katar'ı işgal edecek ve 1915 yılında son Osmanlı askeri birliği bölgeden çekilerek Katar'daki Osmanlı hâkimiyeti sona erecektir.

*dummarbingol@gmail.com.

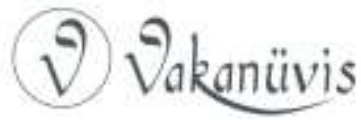


Anahtar Kelimeler: Osmanlı, Katar, İngiltere, II. Abdulhamit, Şeyh Casim, Muhammed Al Sani

\section{A Historical Perspective at the Ottoman Domination in Qatar}

\section{Abstract}

The purpose of this work is to essentially analyse the period starting with Sultan Selim the Stern's Campaign against Egypt, when Qatar came under the rule of the Ottoman Empire, until 1915, when our last soldier left the territories of Qatar. It is understood that the Ottomans fought against first the Portuguese, and after that the British in this region for a long time. The Ottoman army settled in this region for the first time when Sheik Jassim invited Midhat Pasha, the Ottoman Governor of the Gulf Region to Qatar. After that, the Ottoman State started the struggle to establish its sovereignty in Qatar. In order to strengthen its sovereignty in this region, the Ottoman State appointed Sheik Jassim bin Mohammad of the House Al Thani, which was one of the existing houses in the region, as distinct governor of Qatar. Afterwards, Sheik Jassim fought against the Houses in Qatar as well as the neighbouring houses, the House of Saud, and the British for a long time in order to consolidate the Ottoman State's rule in this territory. It is also evident that Sheik Jassim also had conflicts with the Ottoman troops and administration which were present in the region from time to time during his reign.

It is evident in the Ottoman documents involving the reclamations and reforms which were reported by the officers sent to this region in 1888 and 1901 that the Ottoman Empire was particularly concerned about the territory as they were aware of the region's importance. However, while some of the aforementioned reforms were realized, many of them could not be actualized due to the problems the Ottoman state encountered within its geography. It is understood that the British built up the pressure against Sheik Jassim Al Thani in 1894, and he did his utmost efforts to put up a struggle against them. The fact that the British laid claim on Zubarah and Adid on behalf of Bahrain escalated the conflicts in the named regions. Having to put up a long fight in the region, Sheik Jassim Al Thani eventually achieved his goal and succeeded in stationing his own houses in the territory with the support of the Ottoman State.

After that, negotiations involving the region were conducted between the Ottomans and the British between 1910 and 1913, and the British Empire took advantage of the Ottoman State's Balkan Wars and occupied Qatar, and

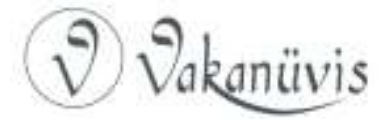


finally the Ottoman rule over Qatar came to an end when the last Ottoman military unit withdrew from the region in 1915.

Keywords: Ottoman, Qatar, Britain, II. Abdulhamit, Sheik Jassim, Muhammed Al Thani

\section{Bölgenin Coğrafi Yapısı ve Genel Tarihi}

Katar, Arap Yarımadası'nın doğusunda bulunan bir Basra Körfezi ülkesidir. Tek kara sınır komşusu Suudi Arabistan olup diğer tarafları Basra Körfezi ile çevrilidir. Kuzeybatısında Bahreyn, batı ve güneyinde Suudi Arabistan, doğusunda Birleşik Arap Emirlikleri ve kuzeyinde İran bulunur.

Katar'ı, coğrafi bölge olarak diğer körfez bölgelerinden ayırmak mümkün değildir. Bölge tarihini araştırırken, Körfez bölgesinin tamamını ele almak gerekir. Mevcut körfez ülkelerinin halklarının büyük bir kısmı tarihte, daha çok çöllerde göçebe olarak yaşamışlardı. Bu yüzden kabileler, o günün şartlarına ve durumuna göre sürekli yer değiştirmişlerdir.

Katar'da tarihi kalıntılar çok az olmakla birlikte bulunduğu bölgedeki ilk yerleşimin taş devrine dayandığı düşünülmektedir. Katar'da Babil ve Selçukluların da yaşadığı bilinir. 7. yüzyılın ortalarından itibaren, İslam dini Arap yarımadasında yayılmaya başlayınca, Katar da Emeviler ve Abbasiler gibi İslam hanedanlarının hâkimiyeti altına girdi. 16. yüzyıldan itibaren ise Osmanlı Devleti'nin denetimine girdi.

Katar'ın iklim ve coğrafi yapısı diğer bölgelerden çok farklı olmadığından burada da yerleşik hayat süren kavimler az olmuştur. Katar daha çok Umman ve Bahreyn'den gelen mevsimlik inci ve balık avcıları için merkez olmuştur. Ancak buraya gelen kabileler belli bir süre burada avcılık yaptıktan sonra bölgelerine geri dönüyorlardı.

\section{XVI. ve XVII. Yüzyıllarda Bölgenin Siyasi Yapısı}

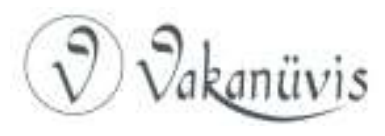


Osmanlı Devleti'nde Katar ile ilgili ilk kaynaklar 16. yüzyılın ortalarından itibaren bilgi vermektedir. Yavuz Sultan Selim zamanında Osmanlı hâkimiyetine giren Arap Yarımadasında klasik merkeziyetçi bir yönetim uygulanmamıştır. Osmanlı, bölgenin idaresini daha çok bölgedeki mevcut kabilelere bırakmıştır. Bölgenin fiziki ve iklim şartları, yerleşik hayatın olmaması, aileler arasındaki çekişmeler ve Osmanlı Halifesine itaatle ilgili bir sorunun olmaması nedeniyle, bölgede merkeziyetçi bir yönetim uygulanmasına ihtiyaç duyulmamıştır. Bu durum Katar için de geçerli olmuştur. ${ }^{1}$

Portekizliler tarafından bu bölgenin 1553 yılından itibaren baskı altına alınmaya çalışıldığı görülmektedir. Umman merkez olmak üzere bu bölgede yaklaşık olarak 150 yıl kalan Portekizlerin iki hedefi vardı. ilk hedefleri bütün haliç bölgesinin ticaretini ele geçirmek, ikinci hedefleri ise bölgeyi Hristiyanlaştırmaktı. ${ }^{2}$ Portekizlilerin bu dönemde Bahreyn ve Katar'da yaşayan kabilelere baskı yapması, Osmanlı'nın Katar'la ilgilenmesine ve bölgeye yönetici atamasına sebep oldu.

Katar ilgili en eski Osmanlı belgesi 1555 yılına aittir. Belge tarihinin Lahsa'nın bağımsız bir beylerbeyliği olarak teşkilatlandığı tarih ile de uyumludur. Belgede, Katar ahalisi tamamıyla gemicilikle uğraştığı, bin yakın gemiye sahip olduğu bu gemileri bazen nakliye, bazen de ticaret için kullandıkları ve ülkenin refahında etkili olduğu belirtilmiştir. Bunların şeyhlerinin adı Muhammed b. Sultan Beni Müsellemdir. Lahsa'da Emlakları bulunan bu kişinin ayrıca Lahsa ile sıkı ilişkileri bulunmaktadır. Aynı zamanda Osmanlı Devleti El Müsellem ailesini, Katar'da hâkimiyeti sağlamak için görevlendirildiği de görülmektedir. ${ }^{3}$

1559 yılında merkezden atanan yönetici Lahsa'ya ${ }^{4}$ ulaştı̆̆ında, Lahsa Beylerbeyi olan Bıyıklızade Mustafa Paşa, Bahreyn seferine çıkmak üzeredir. Beylerbeyi, seferin çok kısa süreceğini ve

1 Zekeriya Kurşun, Necid ve Ahsa'da Osmanlı Hâkimiyeti: Vehhabi Hareketi ve Suut Devletinin Ortaya Çıkışı, Ankara, 2004, s.21-22

2 KK1: Mustafa Aquil Al Hatip

${ }^{3}$ Zekeriya Kurşun, “Osmanlı Devleti'nin Basra Körfezi Siyaseti: Bağdat, Basra ve Lahsa Beylerbeylikleri (1534-1672)", FSM IIImî Araştırmalar insan ve Toplum Bilimleri Dergisi, İstanbul, 2008, s. 21.

${ }^{4}$ Lahsa: Bugünkü Kuveyt'ten yine bugünkü Katar topraklarına kadarki bölgeyi kapsar. Osmanlı döneminde merkezi Katif kenti olmuştur.

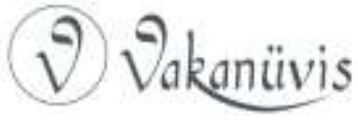


Bahreyn'deki asayişi sağladıktan sonra Katar'a atanan yöneticiyle birlikte Katar'a gitmeyi düşünür. Ancak Bahreyn seferi Beylerbeyinin düşündüğü gibi geçmez. Merkezin iznini almadan, İran etkisindeki Bahreyn'e yapılan seferde Beylerbeyi yenilgiye uğratılarak öldürülür. Bıyıklızade Mustafa Paşa'nın seferde öldürülmesi üzerine merkezden atanan yönetici, ölen beylerbeyinin yerine geçmek zorunda kalarak Katar'a gitmekten vazgeçer. ${ }^{5}$

Portekizliler 1415 yılından itibaren Afrika'da sömürgeciliğe başlar. Osmanlı devleti bölge Müslümanlar ve Açe Sultanlığının isteği üzerine Hint seferine çıkar. Ancak Portekizlilerin Yemen'i işgal etmek istemesi ve bölge Müslümanlarına baskı yapması donanmanın bu bölgeye yönelmesine neden oldu. 1540 yılında yapılan savaşta Yemen Portekizlilerin elinden alınarak Hint seferine devam edilir. Ancak bu seferde Portekizlilerin Umman ve Bahreyn de katliamlar yapması üzerine Maskat'a Piri Reis komutasındaki donanma sefer düzenler. 1552 yılında Maskat vurulur. Hürmüz kuşatılır ancak Piri Reis'in bu seferde başarısız olması üzerine Piri Reis idam edilir. Donanmanın başına da Katif Sancakbeyi Murat Reis atanır. Murat Reis'e donanmanın Süveyş'e götürmesi emir verilir. Hareket halindeyken donanama Hürmüz boğazında Portekizlilerle karşılaşılır, yapılan savaşta Portekizlilere büyük kayıplar verdirilerek Basra'ya geri dönülür.(1554)

1554 yılında donanmanın başına Seydi Ali Reis geçer. Bu seferde Umman açıklarında iki donanma tekrar karşı karşıya gelerek büyük bir çarpışma yaşanır, çarpışma sonunda Portekizlilere ciddi kayıplar verdirilir. Ancak Portekizlilerin merkezlerinin Umman olması onların kısa bir sürede toparlanmalarına neden olur. Gerçeklesen 2. çatışmada iki tarafta ciddi kayıplar verir ve geri çekilmek zorunda kalırlar. ${ }^{6}$

$\mathrm{Bu}$ arada Osmanlı donanmasının Hint seferinden sonra Portekizlerle antlaşma (1561) yapması, Portekizlerin bölgeden çekilmesine ve etkilerinin bölgede azalmasına neden olur. Tehlikenin ortadan kalması üzerine Katar’a başka bir yönetici atanmaz. Bölgenin

\footnotetext{
${ }^{5}$ Kurşun, Necid ve Ahsa'da Osmanlı Hâkimiyeti, s. 24.

${ }^{6}$ Zekeriya Kurşun, Basra Körfezi'nde Osmanlı Ingiliz Çekişmesi, Katar'da Osmanlılar (1871-1916), Ankara, 2004, s.25.
}

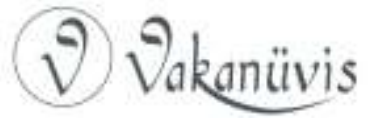


asayiş ve düzeni mevcut beylerbeyi ve bölgeye yerleşmiş ailelerle sağlanmaya çalışıldı. ${ }^{7}$

Al Müsellem ailesi Katar'a 19. yy'ın ortalarına kadar hâkim olur. Ancak ailenin bağlı olduğu Beni Halid kabilesinin Muhammed Bin Suud'la yapılan gazvede yenilerek bozguna uğraması Al Müsellem ailesinin de etkisinin azalmasına neden olur. Uzun süre Bahreyn ve Ummanlı ailelerden Beni Halid kabilesi adına vergi toplayan Al Müsellem ailesi, 1850 yılından sonra Bahreyn ve Umman'daki güçlü ailelerin himayesine girer. ${ }^{8}$

Bahreyn ve Ummanlı ailelerin Katar'ı inci ve balık avcılığı için mevsimlik dönemlerde kullandıklarından bahsetmiştik. Buranın belli dönemlerde kullanılmasının en önemli sebebi, bölgenin kendi yerleşim yerlerine yakınlığı ve bahsi geçen ürünlerin bolluğudur.

Arabistan'ın Necid bölgesinde kuraklık, kıtlık ve aile içi çekişmelerin yaşanması üzerine Al Raşidi, Al Suud, Al Şammar, Al Sani, Al Halife, Al Sabah ve Al Celehme gibi aileler bu bölgeden Ürdün, Suriye, Irak, Kuveyt, Yemen, Umman ve Katar'a göç ederler. ${ }^{9}$ Bu dönemde Al Sani ailesi de, etkisi ve nüfuzu azalan Al Müsellem ailesinin yaşadığı Katar’a yerleşir.

Necid bölgesinden 1695 yılında bölgeye göç eden aslen Genezire kabilesine bağlı olan El Hılf El Uteybi ittifakında olan Al Halife, Al Sabah ve Celehme aileleri Katar'a yerleşmeye geldiklerinde bedevi kültürünün izlerini taşıyorlardı. Bu yüzden de balıkçılık ve inci avcılı̆ı̆ını bilmiyorlardı. 20 yıl boyunca bu bölgede yaşayıp Katar Emirlerine vergi verdiler, bu sırada da inci ve balık avcılığını öğrenerek ticaret yaptılar. ${ }^{10}$

Bu ittifaktaki aileler 20 yılın sonunda Kuveyt'e göç ederek oraya hâkim olup bir yönetim sistemi oluşturdular. Al Sabah ailesi idari yönetimi, Al Halife ailesi ticaret ve hazineyi, Celehme ailesi de denizcilik yönetimini ellerine aldılar. ${ }^{11}$ Yaklaşık olarak 50 yıla yakın bir süre devam eden ittifak, Al Sabah ve Al Halife aileleri arasındaki anlaşmazlıklardan dolayı sona erer (1762). Al Halife ailesi, bu

\footnotetext{
${ }^{7}$ Kurşun, Basra Körfezi'nde Osmanlı Ingiliz Çekişmesi. s.24

8 KK2: Ibrahim Shahdad

${ }^{9}$ https://www.britannica.com/place/Najd Erişim Tarihi:23.02.2019

${ }^{10}$ KK2: Ibrahim Shahdad

${ }^{11}$ KK2: Ibrahim Shahdad
} 
hadiseden sonra Katar'ın Zubara bölgesine dönerek yerleşir. Aile burada yaklaşık 21 yıl kaldıktan sonra Bahreyn'i fethederek bölgenin hâkimiyetini ele geçirir(1783). Al Sabah ailesi ise Kuveyt'i yönetmeye devam eder. ${ }^{12}$

\section{Yüzyılda Osmanlı ve Katar îlişkileri}

1840 yılından sonra Osmanlı belgelerinde Katar'ın tekrar zikredildiğini görüyoruz. İngilizlerin desteklediği Doğu Hindistan İngiliz Şirketi (Lohistan) bu bölgede ticarete başladı. Bu şirket mevcut kabileler ile anlaşarak ticaret ağını genişletti. Şirketin ticari hacminin büyümesi ve nüfuzunun artması kabilelerin içişlerine karışmaya başlamasına neden oldu. Ticari hedeflerle buraya gelen şirket zamanla İngilizlerin telkinleriyle siyasi bir misyon üstlendi.

“ikinci bir durum ise İngilizler, şeyhler üzerinde güç ve etkisini hissettirmek amacıyla, aralarında meydana gelen anlaşmazlıklarda arabuluculuk yaparak, bölge ahalisi üzerinde büyük bir nüfuz kazanmıştı. Ingilizler, Buşir'de konsolosluk açtıktan sonra körfezin tek hâkim gücü konumuna gelmiş ve ${ }^{1869}$ 'da Trucial sahillerinde bulunan bazı Arap aşiret şeyhleri ile yaptığı anlaşmayla, Arap şeyhlerinin Ingilizler dışında hiçbir devletle antlaşma yapmayacağı teminatını almışlardır. Bu gibi çalışmalarını devam ettiren İngilizler, Katar ve Bahreyn'deki etkili şeyhlerle de benzer bir antlaşma yaparak körfeze iyice yerleşmiştir. İngilizlerin çalışmalarında ana hedef, Hindistan ve uzak doğudaki sömürgelerine tehdit oluşturabilecek bir gücün bölgede varlık göstermesine mani olmaktı". ${ }^{13}$

Bu durum Osmanlı Devleti'ni rahatsı etti, bunun üzerine de Osmanlı Devleti bu bölgeyle tekrar ilgilenmeye başladı. ${ }^{14}$

İngiltere önce bir ada olması nedeniyle Bahreyn'i kendisine bağlamış, karadan tehdit edileceği endişesiyle Katar'a müdahale etmemiştir. Raporda,

12 Ahmet Zekeriya Al Şark; Mustafa Aquil, Yusuf ibrahim Abdullah, Tetavur Katar EI Siyesi Min Neşeet Al Imaret ile Istikbal El Devle, Rinode Al Hadise, Doha, 2005, s.182.

13 Oktay Kızılkaya, "XIX. Yüzyılın Sonu XX. Yüzyılın Başlarında Basra Körfezi’nde Uluslararası Hâkimiyet Mücadelesi", International Periodical For The Languages, Literature And History Of Turkish Or Turkic Volume 8/7 Summer Ankara-Turkey, 2013, s.297.

${ }^{14}$ Kurşun, Basra Körfezi'nde Osmanlı Ingiliz Çekişmesi, Ankara, 2004, s. 30-31.

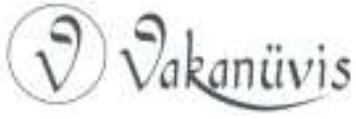


"El-Katar sevahilinde hakimiyet-i Osmaniyye mine'l kadim resmen ve fiilen mevcut olup eşraf-ı mahalliyeden Casim el Sani Bab-ı Ali canibinden ihsan buyrulan kaymakamlık sıfatıyla bir tabur ve iki toptan mürekkep kuvve-i askeriyenin mevcudiyeti hakimiyet-i Osmaniyye içün bir burhan teşkil etmektedir"

denilmek suretiyle Katar'da Osmanlı hakimiyetine vurgu yapılmaktadır. ${ }^{15}$

Katar'daki kabileler Beni Halid kabilesinin nüfuzunun azalmasıyla 1866 yılından itibaren İngilizlerin baskısıyla Bahreyn ve Umman'a vergi vermeye başladılar. Bu durum Katar'daki aileleri rahatsız etmekteydi. Konuyla ilgili şikâyetlerin artması ve kabilelerin huzursuzluğu, 1869 yılında Mithat Paşa'nın Bağdat'a vali olarak atanmasına kadar devam etti. Mithat Paşa uzun bir süre bölgenin durumu ile ilgili araştırma ve incelemelerde bulunduktan sonra, 1871 yılında kendi topraklarımız olan Lahsa'ya ve çevresine askeri sefer düzenledi. ${ }^{16}$

Bu seferin en önemli amaçlarından birisi Osmanlı Devleti'nin Basra Körfezi'nde ve Necid bölgelerinde uzun zamandır kaybettiği mutlak otoritesini tekrar kurmak istemesi ve bölgede otoritesini güvence altına almak için hükümet teşkilatını tesis etme arzusuydu. ${ }^{17}$ ikinci bir amacı da II. Suud devletinin iktidar mücadelesinde İngilizlerin Bahreyn vasıtasıyla Abdullah desteklemeleri ve onu bölgeye hâkim olmasına yardımcı olmaktır. Zira bu dönemde Osmanlı Devleti kardeş Suud'u desteklemekteydi. ${ }^{18}$

Aslında Osmanlı Devletinin amacı yukarıda bahsedildiği gibi bölgede mevcut olan aileler arasında taraf olmak değil, bölgede bulunan aileler arasında oluşan problemleri en kısa yoldan çözüme kavuşturmaktır. Osmanlı Devletinin gücü ve kudreti bölgede bulunan ailelere ve kabilelere ciddi yön vermekteydi. Halifenin emir ve telkinleri Müslüman olan bölge halkı için emir telaki edilirdi. Osmanlı Devleti de olayların hızlı bir şekilde çözümü için bu mekanizmayı kullanmaktan çekinmemiştir.

15 Zekeriya Kurşun, Osmanlı Arap Coğrafyası ve Avrupa Emperyalizmi, Ali Akyıldız, Zekeriya Kurşun, İstanbul, Türkiye İş Bankası Kültür Yayınları, 2015, s.594.

${ }^{16}$ Kurşun, Basra Körfezi'nde Osmanlı Ingiliz Çekişmesi, s.45.

${ }^{17}$ Kurşun, Necid ve Ahsa'da Osmanlı Hâkimiyeti, s.97

18 KK3: Muhammed Hamam

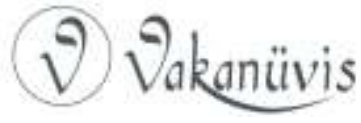


$\mathrm{Bu}$ sefer önceden planlanmış ve tasarlanmıştı. Sefer kendi toprağımızda olmakla birlikte, İngiliz etkisini azaltmak için yapılmış ve sonuçları bakımından başarıya ulaşmıştır.

İngiliz baskısı altında olan, Bahreyn ve Umman'a vergi vermek zorunda kalan Katar Emir'i, bu seferden büyük bir mutluluk ve heyecan duymuştur.

Sefer sonrasında bölgeye gönderilen Nafiz Paşa komutasındaki askeri birlik Katar'a gelir. Katar Emiri Muhammed Al Sani'nin oğlu Casim, Bahreynlilere vergi vermemek ve Suud ailesinin baskınından kurtulmak için evine Osmanlı bayrakları çekerek Osmanlı'ya bağlılı̆ını bildirir.

Bu sırada Suud ailesi, Kuveyt'ten Necid bölgesine geri dönmüş ve Cebeli Şammer Krallığıyla yapılan savaşta Al Şammer Krallığını bozguna uğratarak Necid bölgesinin tamamına hâkim olmuştur. Katar Emiri Muhammed Al Sani uzun bir süre Suud Emiri Faysal Bin Turki adına bölgedeki ailelerden vergi toplamıştır. ${ }^{19}$ Suud kabilesi bununla yetinmeyip nüfuzunu Lahsa bölgesinde genişletmeyi ve vahabilik inancının bölgeye hâkim olmasını istiyordu. İngiltere bölgede kuvvetli bir Osmanlı hâkimiyeti yerine, bir Vehhabi iktidarını çıkarları açısından daha uygun görüyordu. ${ }^{20}$

$\mathrm{Bu}$ durum bölgedeki diğer kabileler için büyük bir sorun teşkil etmeye başladığı için Casim Al Sani babasından farklı düşünerek Ingilizlerin himayesine değil, Osmanlı halifesine bağlı kalmanın daha doğru olacağını düşünüyordu.

Diplomatik bir dille Bahreyn'e ve Umman'a ödediği vergiyi devam ettirmesini isteyen Ingilizlere, Emir Casim Al Sani "Burası Osmanlı toprakları bundan sonra kimseye vergi vermem". ${ }^{21}$ diyerek tekliflerini reddeder.

Mithat Paşa'nın başarılı seferinden sonra buraya yeni bir idari düzenleme getirilir. Bu tarihten itibaren Katar, Basra Vilayetinin Lahsa

\footnotetext{
19 KK2: Ibrahim Shahdad

20 Selda Kaya Kılıç, "19.Yüzyılda Osmanlı İdaresi Altında Basra Vilayeti ve Körfezine Iliş̧kin Bazı Tespitler”, Ankara Üniversitesi Dil ve Tarih-Coğrafya Fakültesi Dergisi, 54/2, 2014, s. 331.

${ }^{21}$ BOA Vesika No: HR. SYS. 114-36:1
} 
sancağına bağlı bir kaymakamlık olarak düzenlenir. Bu talebin de Katar Emir Casim Al Sani'nin isteğiyle gerçekleştirildiği biliniyor. Osmanlı Devleti bu bölgenin merkezden atanan bir kaymakamla idare edilmesinin zor olduğunu bildiğinden, bölgenin birliğini sağlamak için en nüfuzlu ve en güçlü kabilesi olan Al Sani ailesinin lideri Muhammed Al Sani'yi bölge kaymakam olarak atamak ister. ${ }^{22}$ Ancak Muhammed Al Sani bu görevi kabul etmez. ${ }^{23}$ Kabul etmemesinin sebebi 1868 yılında Ingilizlerle bir anlaşma yapması, Osmanlının Suud ailesini desteklediğini düşünmesi ve kabilesinin geleceği açısından İngilizlerin denetimine girmenin daha iyi olacağını düşünmesidir. ${ }^{24}$

Ancak olayın geniş tarafına bakıldığında baba Muhammed Al Sani Ingilizlerle anlaşarak onlarla uzlaşı yolunu aramış, oğlu Şeyh Casim de Osmanlılarla ittifak ederek İngilizlerin yoğun baskısından kurtulmaya çalışarak dengeli bir siyaset uygulama çalışmışlardır. ${ }^{25}$

Muhammed Al Sani'nin oğlu Casim, Halifeye bağlı kalmanın daha doğru olacağını düşündüğünden kaymakamlık görevini üstlenir. Babasının hayattayken önüne geçmesinin bölgenin adet ve geleneklerine uygun olmamasından dolayı Casim Al Sani ancak 1878 yılında babasının vefatından sonra bu göreve dört kolla sarılacaktır. Casim Al Sani aradan geçen beş yıllık süreçte güçlü liderliği ve bütünleştirici kimliğiyle bölgenin tümüne nüfuz ederek bölge birliğini sağlar (18 Aralık 1878). Bu süreçten sonra Casim Al Sani Katar Devleti'nin kurucusu olarak kabul edilir ve bu tarih ileride Katar'ın milli günü olarak kutlanacaktır.

Casim Al Sani çocukluğundan itibaren bölgenin en iyi âlimlerinden dersler almış, entelektüel, siyaseti iyi bilen, olayları doğru okuyan ve karizmatik bir kişiliğe sahiptir. İslam birliğine destek verdiği için İstanbul'daki halifeye bağlı kalmayı hep tercih etmiştir. Ingilizlerle ticaret ilişkisine devam etmesine rağmen hiçbir zaman onlara güvenmemiştir. İngilizler de Casim Al Sani'ye hep şüpheyle yaklaşmışlardır.

\footnotetext{
22 BOA Vesika No: HR. SYS $114-36: 4$

${ }^{23}$ BOA Vesika No: HR. SYS $114-38: 2$

24 KK2: Ibrahim Shahdad

25 Mohammed Yousef Al Abdullah, Şeyh Casim Zamanında Katar'da Osmanlı Ingiliz Çatışması, Basılmamış Panel Konuşması, 12 Aralık 2018 Katar Milli Kütüphanesi), 2018.
}

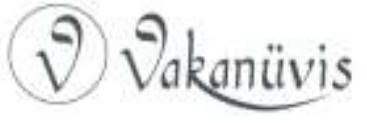


1880 yılında İngilizlerin baskıların artması sonucu Casim Al Sani'nin bölgede Osmanlı hâkimiyetini sağlamak için çok fazla mücadele ettiği görülür. Mücadelesi sırasında Osmanlı memurlarından yardım almaması, gazvelerde Osmanlı askerlerini kullanmaması memurları fazlasıyla rahatsız eder. Katar'daki bazı aileleri hâkimiyeti altına alma sırasında da ölümlerin olması ve bu ailelerden zekât adı altında vergi toplaması memurları ziyadesiyle rahatsı eder. Durumu üstlerine bildirerek Casim Al Sani'yi Bâb-ı Âli'ye şikâyet ederler.

Aynı dönemde Al-Vakra'nın etkin eşraflarından olan Muhammed Bin Abdulvahhab, Casim Al Sani'nin kendisinden zekât istemesi üzerine şikâyetçi olur. Casim Al Sani ile ilgili bölgede görevli bütün beylerbeylerine dilekçeler gönderir. Dilekçelerinde Casim Al Sani'nin görevden alınması ister. Daha önce memurların da şikâyetleri BâbıÂli'ye iletilir, memurlar da başına buyruk olan kaymakamın (Casim Al Sani) görevden alınmasını isterler. Bütün bu şikâyetlere rağmen BâbıÂli, Casim Al Sani'nin kaymakamlıktan almayı uygun görmez.

1883 yılında gelindiğinde İngilizler, Katar'ı hâkimiyet altına almak için Hindistan'da eğittikleri Banyan tüccarlarını Katar'daki nüfuzlarını artırmaya çalışır. İngilizler bu tüccarların Katar'daki aileler ile iyi ilişkiler kurmalarını sağlar ve bölgede ticaret yapmaları için teşvik eder. Ancak Casim Al Sani bunların geliş amacının farkındadır ve bu durumu BâbıÂli'ye bildirir. İngilizler tüccarların küçük meselelerini bahane ederek, Katarlı ailelere ve Casim Al Sani'ye baskı yapar ve vergi almaya çalışır. Bu baskılar sonucunda Casim Al Sani ticaretine devam edebilmek için Ingilizlere senet imzalamak zorunda kalır. ${ }^{26}$

Durumu Basra ve Necid memurlarına bildiren Casim Al Sani memurların bu olay karşısında sessiz kalması ve yardım etmemesine çok sinirlenir. 1884 yılında Necid mutasarrıfına istifa dilekçesini verir. Bölgedeki memurlar Casim Al Sani'nin istifasının kabul edilmesi için Bâb-ı Âli'ye telkinlerde bulunur. Ancak Bâb-ı Âli bu istifayı da kabul etmez. Her şeye rağmen Casim Al Sani ile devam etmek ister. Çünkü Casim Al Sani'nin yanlışlıkları olmakla birlikte İngilizlere karşı Osmanlı Devleti adına Katar'da çok ciddi bir mücadele verdiği ve İngilizlerin Katar hâkimiyetini engellediğinin farkındadır. Bir buçuk yıl sonra 1885

${ }^{26}$ BOA, Arşivi Vesika No: HR. TO. 60 - 52 s.2.

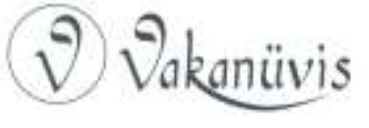


yılında Casim Al Sani ikinci kez istifa dilekçesini gönderir ve bu sefer de istifasının kabul edilmemesi halinde bölgeden göç edeceğini söyler ancak bu istifa da Bâbı-Âli tarafından kabul edilmez ve kaymakamlık görevine devam etmesi istenir. Konunun araştırılması için bölgeye müfettişler gönderilir. Müfettişlerden Al-Vakra'nın önde gelenlerinden Abdullah Bin Abdulvahhap ile Casim Al Sani'nin barıştırılması istenir. Böylece Casim Al Sani'nin istifası da ikinci kez engellenmiş olur.

Bu dönemde ilginç olan durum bölgede görevli olan memurların, bölge dinamiklerini ve Şeyh Casim'in İngilizlerin yayılımcı politikalarına karşı verdiği mücadelesini çok iyi okumadıkları anlaşıımaktadır. Şeyh Casim içeride ve dışarıda birçok güçle mücadele etmek zorunda kaldığıdır. Bu durumun Osmanlı Devleti'nin sahadaki memurlarını rahatsız etmesi de anlaşılır olmakla birlikte anlık ve duygusal tepkileri bu sonuçların ortaya çıkmasına sebep olmuştur. Ancak mevcut sorunlar Bab-ı Ali tarafından çok düzgün okunduğu, duygusal, anlık ve hamasi kararlar yerine mantıklı, iyi düşünülmüş ve doğru kararla aldıkları görülmüştür.

1888 yılında II. Abdülhamid'in bu bölgeyle özel ilgilendiği ve bu bölge ile ilgili raporlar hazırlattığı görülür. Onun bu planları hazırlatması İngilizlerin bu bölgede nüfuzlarını tekrar attırdığı döneme denk gelir. Raporlar hızlı bir şekilde uygulamaya geçer. Bu raporlarda Zubara ve Ubeyd'e liman ve posta teşkilatının kuruması, vergi binalarının inşaatı ve hükümet binalarının kurulmasının yanında(Al Abdullah,2018) Katar'ın Osmanlı Devleti'nin bir parçası olduğu, Basra ve Lahsa'dan sonra bu bölgede üçüncü eyalet ilan edilmesi planlanır. ${ }^{27}$ Malesef bu plan dönemin şartlarından dolayı gerçekleştirilemeyip proje aşamasında kalmıştır.

Aynı zamanda bu dönemde Osmanlı Devleti tarafından 29 Şubat 1988 yılında hizmet ve sadakatinden dolayı Şeyh Casim'e KAPICIBAŞı unvanı verilir. ${ }^{28}$

Osmanlı Devleti bu unvanı Şeyh Casim'e vererek, ona güvendiklerini ve onun Osmanlı'ya bağlılık sadakatinden şüphe duymadıklarını ifade etmiş oluyorlardı. Bunun yanında bölgede mevcut olan diğer aşiret ve

\footnotetext{
27 KK4: Ali Abdullah ibrahim Al-Ensari.

${ }^{28}$ Kurşun, Basra Körfezi'nde Osmanlı Ingiliz Çekişmesi, s.84.
}

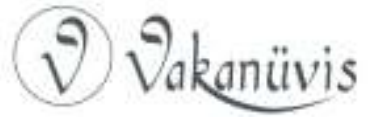


kabilelere bizim bölgedeki tek temsilcimiz Şeyh Casim olduğunu ve bölgedeki herkesin ona bağlı kalması gerektiği mesajını da vermiş oluyorlardı.

Bölgenin jeopolitik konumu elverişli olduğundan inci, balık rezervleri ve İngiliz kışkırtmaları yüzünden kabileler sürekli birbirleriyle sorunlar yaşamaktaydı. Dönemin güçlü ailelerinden Abu Dabi Şeyhi Zayet ve Katar Emir'i Casim Al Sani arasındaki sıkıntılar artmaya başladı. Ingilizlerin kışkırtmaları ve tahrikleri ile bu iki kabile karşı karşıya geldi. Casim Al Sani'nin II. Abdülhamit'ten yardım istedi ancak II. Abdülhamid iki Müslüman kabilenin arasındaki ihtilafta taraflardan birini destekleyerek onları karşı karşıya getirmenin olumsuz sonuçlar doğuracağını düşündüğü için bu teklife olumlu cevap vermedi. ${ }^{29} \mathrm{Bu}$ durum İngilizlerin işine yarar. İngilizler Şeyh Casim Al Sani'ye kendileriyle işbirliği yapması şartıyla yardım edebileceklerini söylerler. Şeyh Casim Al Sani İngilizlere güvenmemesine rağmen kabilesinin geleceği için bu teklifi kabul eder. Ama hiçbir zaman İngilizlerin himayesine girmeyi de düşünmez.

1892 yılında Hannur Gazvesi ile Ebu Dabi yenilgiye uğratılır. Casim Al Sani büyük bir başarı kazanıp bölgedeki nüfuzunu attırır. Ancak Casim Al Sani'nin bu bölgede nüfuzunu arttırması Osmanlı Devleti'nin işine gelmez. Nüfuzunu hızla arttıran Casim Al Sani'yi durdurmak için bölgeye yeni bir yardımcı kaymakam atanır. Bu hamle çok başarılı olmayınca 1893 yılında Basra valisi olan Mehmet Hafız Paşa buraya bir donanmayla gelir.

\section{Vecbe Hadisesi}

Bu seferin nedeni Casim Al Sani'nin İngilizlere bağlandığı vehmi gibi görünse de aslında en önemli sebep, Dorin bölgesinin şeyhi Mehmet Al Feyhani'nin Katar'a kaymakam yapılmak istenmesidir. ${ }^{30}$ Osmanlı belgelerinde bölge müdür ve memurların istanbul'a yazdıkları mektuplarda İngilizlerin saldırılarına Osmanlı Devletinin gerekli ehemmiyeti göstermediğinden dolayı bölge halkının hayal kırıklı̆ı ve şaşkınlık içinde olduklarının bölgede görevli asker ve memurlara ilgi ve alaka göstermedikleri askerlerin bazen kaleden çıkmalarına müsaade

${ }^{29}$ BOA, Vesika No:HR. TO. 392-50, s.1

${ }^{30}$ KK4: Ali Abdullah İbrahim Al-Ensari

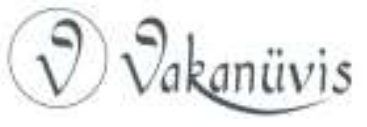


etmedikleri ve bir Osmanlı askerinin darp edildiği yazılmış ama bunların olağan ve geçici olduğunu Osmanlı Devletinin buraya bir birlik göndermesine gerek olmadığı sadece Padişah'ın göndereceği bir nasihat fermanıyla olayın tatlıya bağlanacağı kaleme alınmıştır. ${ }^{31}$ Mehmet Hafız Paşa 27 Şubat 1893'te donanmayla Katar sahillerine geldiğinde Katar Kaymakamı Casim Al Sani'yi gemiye çă̆ırır. İngilizlerin Casim Al Sani'ye "Oraya gidersen seni tutuklar veya öldürebilir" demesi üzerine, Casim Al Sani kabilesi ile birlikte Katar'ın içlerine çekilir. Bunun yanında Şeyh Casim hasta ve yaşlılığını bahane ederek kaymakamlıktan çekildiğini bildirir. ${ }^{32}$ Vali bu duruma çok sinirlenir ve ikili arasında müzakereler başlar. ${ }^{33}$

Katar adına müzakereyi yapmak üzere Casim Al Sani'nin kardeşi Ahmet Bin Muhammed ve 11 kişiden oluşan bir ekip gider. Ancak müzakereci grup Vali Mehmet Hafız Paşa tarafından esir alınır. ${ }^{34}$ Bunun yanında vali bir grup askeri (370 civarı) karaya çıkararak Osmanlı Kalesi'nde konuşlanmış Osmanlı müfrezesinin yanına gönderir. ${ }^{35}$

Askerlerin karaya çıkarken küçük çatışmalarda can kayıplarının olması, Osmanlının kendilerini İngilizlere karşı yalnız bıraktığı hissi ve en önemlisi Osmanlının Zubara ve Ubeyd'de gümrükler inşa ederek yabancı tüccarlardan vergi toplayacak olması gibi hususlar kabileleri rahatsız etmişti. Yaklaşık 4000 kişilik bir kuvvetle karaya çıkan askerlere saldırarak 118 askeri şehit edip 55'ini yaraladılar. ${ }^{36}$

Bu olay tarihe Vecbe Hadisesi (25 Mart 1893) olarak geçer. Vecbe Hadisesi Katar'ın milli kimliğini oluşturmada çok önemli bir olay olarak kabul edilecektir. Bu hadiseden sonra da Katar Osmanlılardan uzaklaşmaya başlar.

Vecbe

hadisesinden sonra II. Abdülhamid'e mektup yazan Casim Al Sani kendisinin Osmanlı'ya ihanet etmediğini, olayın müsebbibinin Mehmet Hafız Paşa'nın tahrikleri olduğunu bildirip bu olayın tetkik edilmesini ve

\footnotetext{
${ }^{31}$ BOA, Vesika No: $1123-84151-1$ ve $1124-84246-1$

32 Al Abdullah, a.g.y.

33 BOA, Vesika No: BEO 796-59642.

${ }^{34}$ BOA, Vesika No: HR. TO. 399 -7, s.4.

${ }^{35}$ Kurşun, Basra Körfezi'nde Osmanlı Ingiliz Çekişmesi, s.98.

${ }^{36}$ Kurşun, Basra Körfezi'nde Osmanlı Ingiliz Çekişmesi, s. 98.
}

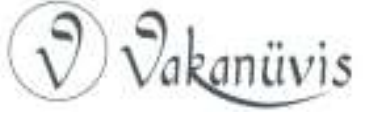


esir alınmış adamlarının serbest bırakılmasını ister. ${ }^{37}$ Olay Osmanlı tarafından tetkik edildikten sonra Basra Valisi Mehmet Hafız Paşa'nın merkezden onay almadan kendi vehim ve inisiyatifi ile bu olaya sebep olduğu anlaşılır ve görevinden uzaklaştırılır. Akabinde esirler serbest bırakılır. Şeyh Casim Al Sani Osmanlı Devleti'ne bağıı kalacağını söyler. Ancak olayın başka kabileler için kötü örnek olmasını engellemek ve geleneksel idari yapının sürdürülmesini sağlamak, bölgenin birliği için önemli görüldüğünden Osmanlı devleti kaymakamlık görevini kendisinden alarak kardeşi Ahmet Bin Muhammed'e verir ayrıca yanına merkezden görevlendirilen bir kaymakam yardımcısı atar.

Ahmet Bin Muhammed'in kaymakam olarak atanması Casim Al Sani'yi rahatsız eder. Casim Al Sani İngilizlerin denetiminde olan Hintli tacirleri taciz ederek İngilizlerin Osmanlı'ya baskı yapmasını ve bölgede huzursuzlukların çıkmasını ister. ${ }^{38}$ Ancak 1905 yılında Ahmet Bin Muhammed'in göçmen kabileler tarafından kişisel bir mesele yüzünden öldürülmesi üzerine Casim Al Sani buraya tekrar kaymakam olarak atanır. Osmanlı Devleti'nin Şeyh Casim Al Sani'yi kaymakam olarak atamasının en önemli nedeni mevcut kabilelerin kendisinden başka kimse tarafından kontrol edilemeyeceğinin düşünülmesidir.

1894 yılından itibaren İngilizlerin Katar'a baskısını artığını görüyoruz. Aslen Katarlı olan ancak ticaret yapmak için Bahreyn'e yerleşen Al Bin Ali aşireti. ${ }^{39}$ Bahreyn'deki baskılardan kurtulmak için 2000 yakın aşiret efradıyla Zubara'ya yerleşir. Bu durumdan rahatsız olan İngilizler aşiretin hemen Bahreyn'e dönmesini ister. Çünkü uzun bir süreden beri İngiltere Zubara ve Udeyd'in Bahreyn'in toprağı olduğunu savunuyordu. Al Bin Ali aşiretinin olumsuz cevap vermesi üzerine İngiltere donanması 4 gün 4 gece Zubara'yı topa tutarak yaklaşık olarak limanda inci avcılığı için kullanılan 1000 yakın gemini büyük bir kısmını yakarak bir kısmına da el koyarak şehirdeki evleri, hükümet konağını, resmi binaları ve ibadethaneleri yıkıp ve tahrip ederek Al Bin Ali aşiretinin yüzlercesini öldürdükten sonra geri kalanın büyük bir kısmını zorla tekrar Bahreyn'e geri götürür. Al Bin Ali aşiretinin reisi Şeyh Sultan Bin Muhammed Selame ve yakın ailesinden

\footnotetext{
${ }^{37}$ BOA, Vesika No: HR. TO. 397-7, s.3.

38 KK2: Ibrahim Shahdad

${ }^{39}$ BOA Vesika No: HR -SYS - 108 - s.3.
}

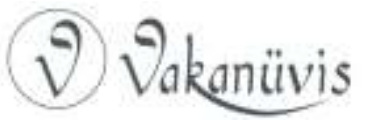


50 kişi bir ekip ise Katar'ın içlerine kaçarak Bahreyn'e gitmeyi ret eder. ${ }^{40}$

Bu olaydan sonra İngiltere Al Bin Ali aşiretinin Zubara'ya yerleştirilmesinden sorumlu tuttuğu Şeyh Casim Bin Sani'nin Ingiltere'ye zarar tazminatı ve ele koydukları gemileri geri vermek için 30000 bin rubye vermesini ve belirtilen süre zarfında ödenmediği takdirde gemilere el koyacağını bildirmiştir. Şeyh Casim Al Sani olayı Babı Ali'ye bildirdikten sonra Katar halkını tek geçimi olan inci avcılığının yapılmaması durumunda halkın yaşayacağı sıkıntıdan dolayı bu bahsi geçen parayı İngiltere'ye vermek zorunda kaldığını bildirir. ${ }^{41}$

1897'den sonra Katar'ın İngiltere'ye karşı dik durması ve Osmanlı'nın yanında saf tutması bölgedeki aşiretlerin Katar ile mücadelesi artırdığını görmekteyiz.

1900 yılında Kuveyt Şeyh'inin kardeşi Mübarek Al Sabah Katar topraklarına saldırdığı ve çıkan çatışmalarda 220 erkek, 25 kadın ve 42 çocuk toplamda 287 kişiyi öldürdüğü ve 2000 yakın deve, 100000 koyun, 500 kısrak ve yaklaşık olarak 5 bin liralık mal aldığı bildirilmiştir. Bunlar Şeyh Casim'in mektubunda belirtildiği gibi bu hayvanlardan 1800 devenin, 3500 koyunun ve 60 kısrağın kendisine ait olmadığını halkın malı olduğunu belirtmiştir. ${ }^{42}$

Bu olay sonra Katar halkı arasında büyük bir üzüntüye sebep olacak ve Katarlılar bunun intikamını almak için mücadele vereceklerdir. Ancak Osmanlı memurlarının ve Osmanlı askerlerinin buna izin vermeyeceklerini belirtmeleri üzerine Şeyh Casim Al Sani Bab-ı Ali'ye bir mektup yazarak meselenin aydınlatılması ve Mübarek Bin Sabah'ın cezalandırılması için tahkik memurlarının bölgeye gönderilmesini ister. ${ }^{43}$

2 Ağustos 1314 yılında kaleme aldığı mektupta Casim Bin Muhammed Al Sani basit meseleler için Basra'dan buraya askerlerini sevk edenler Mübarek Al Sabah'ın Katar aşiretin üzerine yürümesini ve saldırı hazırlığında olduğu söylememize rağmen bizim vehmimize veren

\footnotetext{
${ }^{40}$ BOA Vesika No: BEO - $796-59642$, s. 2.

${ }^{41}$ BOA Vesika No: BEO - $796-59642$ - s.2.

42 BOA Vesika No: BEO - $1178-88343-$ s.3.

${ }^{43}$ BOA a.g.b. s.3.
} 
ve abartılı görenler ve bu olayları merkeze bildirmeyenler bu kadar Müslüman ölümünden sorumludur. Mübarek Al Sabah'a muhabbet ve salahiyet besleyen yetkililerin ve bizi mağduriyetimizden tereddüt eden var ise harcırahı aşiretler tarafından karşılanmak üzere tarafınızdan sadık bir tahkik memurunun gönderilmesi, tereddüt yok ise aşiretlerin umutsuzluk içinde bırakılmaması için ve mazlumların içindeki ateşini söndürülmesi için kolunuz halife makamına hitaben yazdığım fermanın adaletin mümessili $\mathrm{Hz}$ padişah olaya müdahale etmesi ve hızlıca tarafımıza cevap verilmesi arz ve istihdam ederim. ${ }^{44}$

Şeklinde bir mektup yazarak olayın çözüme kavuşması ve Mübarek el Sabah'ın aldıkları ya da çaldıkları geri getirerek Katar halkının mağduriyetin giderilmesi istemişti.

1900 yılında Osmanlı Devleti Katar'ın Zubara ve Ubeyd nahiyelerine müdürler atar. Zubara'ya Arap Efendi, Ubeyd'e ise Abdülkerim Efendi atanır. ${ }^{45}$ Ancak bu iki nahiyenin yerleşime açık olmaması ve İngilizlerin Bahreyn adına buraya da hak talep etmelerinden dolayı atanan memurlar belirtilen yerlere gidememişlerdir. Katar merkezde kalmışlardır. Yapılan yazışmalarda bu nahiyelere atanan müdürlerin oraya gitmesi için her bir memura 100 kişilik bir birlik verilmesi ve bunların ihtiyaçlarını rahat karşılayabilmeleri için de bir geminin tahsis edilmesi istemişti. ${ }^{46}$

Bununla birlikte Şehy Casim Bab-ı Ali'ye yazdığı mektupta Osmanlı'nın Zubara'da sadece bir hükümet konağı inşa edip bayrağını oraya dikmesi halinde geri kalan inşaatların aşiretler tarafından karşılanacağı ve Zubara'nın yerleşimi açılabileceği belirtilmişti. ${ }^{47}$

Aynı dönemde de Osmanlı Katar'ın bölgedeki öneminin artması üzerine burada 10 maddelik bir de ıslah çalışması hazırlatmış ancak maalesef İstanbul'da ve Balkanlar'da gelişen süreçten dolayı istenilen reformlar gerçekleştirilememiştir. Yapılması planlana ıslahatlar şu şekilde belirlenmişti.

1- Bölgede yeni kaymakamlık ve idari birimler kurulacak.

\footnotetext{
44 BOA a.g.b. s.3.

45 BOA Vesika No: DH. TMIK. S. 42 - 5- s.43.

${ }^{46}$ BOA Vesika No: DH. TMIK. S. - s.25.

${ }^{47}$ BOA Vesika No: HR. SYS 94 - 8 s.36.
}

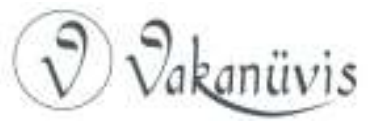


2- Bölgeden zekât dışında hiç bir vergi alınmayacak. Masraflar dışında artan zekâtlar halka dağıtılacak.

3- Yeni devlet daireleri inşa edilecek, eski olanlar tamir edilecek.

4- Toprak ıslahı yapılarak, halka tapuların verilecek.

5- Tapu masrafları alınmayacak, tapular ekili alanlar ve münhal alanalar olarak ikiye ayrılacak.

6- Bölgede camiler, mescitler ve vakıf binaları inşa edilecek.

7- Okullar, yetimhaneler inşa edilecek, dullar için yardım sandıkları kurulacak.

8- Tohum ıslahı yapılarak, buğday ve arpanın ekimi teşvik edilecek.

9- Bölgede yolların güvenliği için karakollar ve kışlalar inşa edilerek, mühimmat kömür depoları yapılacak.

10- Osmanlı askerlerine güvenin artırılması için halkın eşkıyalardan korunup ollanarak devletin sıcak yüzünün gösterilmesi. ${ }^{48}$

1903 yılına gelindiğinde Katar gelip yerleşen aşiretlerin sayısının artığı görülmektedir. Bu tarihte yapılan nüfus sayımına göre Katar'ın nüfusu 13500 kişi olduğu tespit edilmiştir. ${ }^{49}$

Bu süreç 1913 yılına kadar devam eder. Casim Al Sani'nin Osmanlı halifesine bağlıı̆ıını bildirmesi, İngilizlerle Katar arasındaki çekişmelerin artarak sürmesine neden olur. İngilizlerin Zubara bölgesine Bahreynli aileleri yerleştirmesi üzerine Casim Al Sani de Katarlı kabileleri buraya yerleştirerek onlara karşı hamle yapar. Bu hamleyle İngilizlerin Katar'da hâkimiyet kurmasının önüne geçilir.

1906 yılında ise Casim Al Sani'nin oğlu Şeyh Abdullah, Osmanlı Devleti tarafından önce Al-Vakra'ya memur olarak daha sonra da kaymakam yardımcısı olarak atanacaktır. ${ }^{50}$

1907 yııında Şeyh Casim'in yazdığı şiir divanı Hindistan'da basılarak kitap haline getirilir. Divan yedi bölümden oluşur. Her bir bölümünde hayatındaki önemli olayalar anlatılmaktadır. ${ }^{51}$

\footnotetext{
${ }^{48}$ BOA Vesika No: HR. SYS. $108-3$ s.3.

${ }^{49}$ BOA Vesika No: DH. TMIK. S. $42-$ s. 2.

50 BOA Vesika No:HR. SYS 94-8 s.6.

${ }^{51}$ KK3: Muhammed Hamam.
}

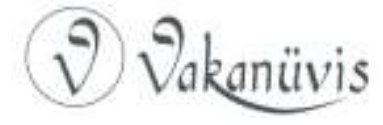


Şeyh Casim'in mal varlığı kesin olarak ne kadar olduğu bilinmemekle birlikte İngilizler tarafından 1913 yılında kaleme alınmış bir belgede, nakit 70000 bin rupi, 20000 dolar, 6000 Türk lirası, inci ticaretinden 600000 rupi, verdiği borçlar 150000 rupi, köle değeri 100 000 rupi, at ve deve değeri 200000 rupi şeklinde kaleme alınmıştır. ${ }^{52}$

\section{0 - 1913 Osmanlı ve İngiliz Müzakereleri ve Katar'ın Osmanlılardan Ayrılması}

1910-1913 yılında Osmanlı ve İngilizler arasında Körfez bölgesi için uzun müzakereler yapılır. Bu müzakerelerle Osmanlı'nın en büyük hedefi, öncelikle bu bölgeyi elinde tutmaya çalışmak, bunun mümkün olmadığı durumda, bölgenin özerk bir yapıya kavuşturulması yoluyla İngilizlerin hâkimiyetini engellemektir.

23 Temmuz 1913'te Londra'da imzalanan ancak yürürlüğe girmeyen Londra Antlaşmasının Katar ile ilgili maddesi gereğince Osmanlı Devleti Katar üzerinde geçmişten süregelen hakları ve taleplerinden feragat etmiştir. ${ }^{53}$ Bölge Casim Bin Sani ve haleflerinin yönetimine bırakılmıştır.

Katar'ın İngilizlere bırakılması halk arasında büyük bir üzüntü ve hayal kırıklığına sebep olur. Şeyh Casim kaymakamlığının son aylarında Osmanlı Devletinin Balkan Savaşına destek olmak için 25000 rupi gibi önemli bir bağışta bulunmuştur. ${ }^{54} 1913$ yılında Şeyh Casim, vefatından kısa bir süre önce Osmanlı Devleti'nin onayıyla oğlu Şeyh Abdullah lehine kaymakamlıktan çekilerek görevi ona devreder. İngilizler Osmanlı Devleti'nin Balkan savaşlarını fırsat bilerek Katar'ın tamamen hâkimiyetini ele geçirir. Bunun üzerine bölgede mevcut olan son Osmanlı askeri müfrezesi (80-100 kişi) Ağustos 1915'te çekilir.

1916 yılında İngilizler Katar’ı bölge ittifakının içine alarak buradaki hâkimiyeti eline geçirir. Katar bu ittifak dâhil olan en son Körfez bölgesidir.1918 yılında da Osmanlı Devleti ve İttifak Devletleri arasında

\footnotetext{
52 KMK İngiliz Arşivi Belge No: IOR-R26-2-15,s.151.

53 Birol Başkan, "Calutlar Dünyasında Bir Davut: Katar'ın Dış Politika Dinamizmi", Akademik Ortadoğu,7/12, 2012, s.35.

${ }^{54}$ Al Abdullah a.g.y.
}

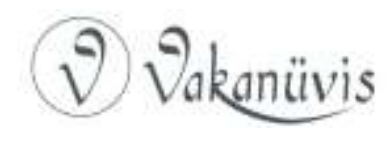


yapılan Mondros Ateşkes Antlaşması ile burası resmen İngilizlere bırakılır.

Katar'da 1960 yılına kadar Halife II. Abdülhamit adına hutbe okutulduğu bilinmektedir. ${ }^{55} \quad$ Katar'a Osmanlı tarafından kaymakam yardımcısı atanması ve kararların alınmasında istişare kültürünün önemsenmesi diğer Körfez bölgelerinden farklı olarak bir devlet geleneğinin, modern ve model bir idare yönetiminin oluşmasını sağladı.

Her ne kadar Osmanlı'dan fazla eser kalmasa da Doha Corniche (Korniş) Bölgesi'nin Wadi mıntıkasında, Katar Divan Emir'inin ana giriş kapısı yanında Osmanlı Kalesinin izleri halen mevcuttur. Bu bölümde Osmanlı askerlerinin mezarları ve at harasının izlerine rastlanmaktadır. Bunun yanında Souk Vakıf bölgesinde bulunan Ebu El Kubeb Camisi de Osmanlılardan kalmadır. Ama ne yazık ki cami 1980 yılında tamamen yıkılarak mevcut yerine şu an yeni bir cami yaptırılmıştır.

\section{Sonuç}

Bu çalışmanın en önemli amacı, başta Katar yarımadası olmak üzere Osmanlı devletinin Basra körfezini nasıl yönettiği hakkında fikir sahibi olmaktır. Makalemizde ağırlıklı olarak Osmanlı'nın Katar'ı hâkimiyetine almasından başlanarak, bölgeden son askerimizin çekilmesine kadarki süreç ele alınmıştır. Bu çalışma yapılırken sahada Katar tarihi ile ilgili olarak en ciddi çalışmanın Prof. Dr. Zekeriya Kurşun tarafından yapıldığı da görülmüştür. Katarla ilgili olarak Zekeriya Kurşun tarafından yazılmış iki kitap bulunmaktadır. Bunlar "Basra Körfezinde Osmanlı-İngiliz Çekişmesi, Katarda Osmanlı 1871-1916" ile "Necid ve Ahsa'da Osmanlı Hâkimiyet Vehhabi Hareketi ve Suut Devletinin Ortaya Çıkışı" isimli kitaplardır.

Bu makalede, Osmanlı arşivlerinin yanında tarihçiler ve Katar milli kütüphanesinde bulunan İngiliz arşivlerinden yararlanılarak, Osmanlının Katar'da bıraktığı izler üzerinde duruldu. Makalenin bu alanda çalışma yapacak araştırmacılara ışık tutması ve yardımcı olması en büyük temennimizdir.

55 KK4: Ali Abdullah İbrahim Al-Ensari

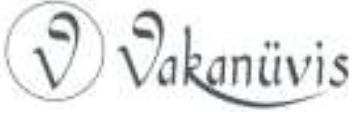


Makalede Osmanlı'nın bölgede mevcut olan aşiretlerle nasıl dengeli bir politika takip ettiği ve aşiretlerin Osmanlı’ya bağlı kalması için verdiği mücadeleyi görüyoruz. 1540'tan itibaren önce Portekizlilerle Basra ve Hürmüz Boğazında mücadele ettiği, akabinde uzun bir süre karada ve denizde İngiltere ile verdiği mücadeleyi açıklıkla anlatılmaya çalışılmıştır. İngilizlerin bölgeyi denetimleri altına almak için hiçbir fırsatı kaçırmadığı, her fırsatta Osmanlı Devletini kötüledikleri ve bölgede bulunan aşiretleri onlara tabi olmaları için uyguladığı baskılar irdelenmiştir. Buna karşılık İngiltere'nin bu tavırlarına karşı gelen ve Osmanlı'nın yanında dik bir duruş gösteren kabilelere uyguladığı baskı açıklıkla anlatılmıştır.

Aynı zamanda bu çalışmada Katar Emiri Şeyh Casim'in komşu kabilelerle mücadeleleri, Osmanlı Devleti ve II. Abdülhamit Hanla olan samimi ve içten münasebetlerini ortaya koymaya ve bu samimiyetin neden ve sonuçlarını irdelemeye çalıştık.

Çalışmanın sonunda Osmanlı Devletinin bölgede bıraktığı tarihi yapı ve eserlerden de bahsedilerek günümüz Katar'ında var olan Osmanlı mirası da ele alınmıştır.

\section{KAYNAKLAR}

\section{Kitaplar}

AL ŞARK, Ahmet Zekeriya; Mustafa Aquil, Yusuf ibrahim Abdullah (2005), Tetavur Katar El Siyesi Min Neşeet Al İmaret Ile İstikbal El Devle, Rinode Al Hadise, Doha

KURŞUN, Zekeriya (1998), Necid ve Ahsa'da Osmanlı Hâkimiyeti: Vehhabi Hareketi ve Suut Devletinin Ortaya Çıkışı, Ankara

KURŞUN, Zekeriya (2004), Basra Körfezi'nde Osmanlı İngiliz Çekişmesi, Katar'da Osmanlılar (1871-1916), Ankara

KURŞUN, Zekeriya (2015), Osmanlı Arap Coğrafyası ve Avrupa Emperyalizmi Ali Akyıldız, Zekeriya Kurşun İstanbul, Türkiye İ̧̧ Bankası Kültür Yayınları

\section{Makaleler}

AL ABDULLAH, Mohammed Yousef (2018), Şeyh Casim Zamanında Katar'da Osmanlı İngiliz Çatışması Basılmamış Panel Konuşması, 12 Aralık 2018 Katar Milli Kütüphanesi)

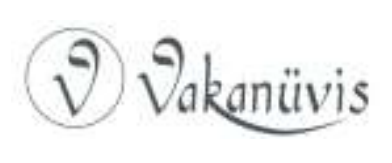


BAŞKAN, Birol (2012), "Calutlar Dünyasında Bir Davut: Katar'ın Dış Politika Dinamizmi", AkademikOrtadoğu,Cilt:7,Sayı:12, http://www.akademikortado gu.com/belge/ortadogu13makale/birol_baskan.pdf (01.03.2019)

KILIÇ Selda Kaya (2014), 19.Yüzyılda Osmanlı İdaresi Altında Basra Vilayeti ve Körfezine İlişkin Bazı Tespitler, Ankara Üniversitesi Dil ve Tarih-Coğrafya Fakültesi Dergisi 54, 2, 319-336

KIZILKAYA, Oktay (2013), XIX. Yüzyılın Sonu XX. Yüzyılın Başlarında Basra Körfezi'nde Uluslararası Hâkimiyet Mücadelesi, International Periodical For The Languages, Literature And History Of Turkish Or Turkic Volume 8/7 Summer Ankara-Turkey

KURŞUN, Zekeriya (2008), Osmanlı Devleti'nin Basra Körfezi Siyaseti: Bağdat, Basra ve Lahsa Beylerbeylikleri (1534-1672), FSM IIlmî Araştırmalar İnsan ve Toplum Bilimleri Dergisi, İstanbul

YURDAKUL ÖZKAPLAN, Dr. Nurcan, Osmanlı Asırlarında İngilizlerin Basra Körfez'inde Yerleşme Çabaları (Seminer)

Arşiv Belgeleri

Katar Milli Kütüphanesi İngiliz Arşivi(KMK)

Başbakanlık Osmanlı Arşivi (BOA)

Internet Kaynakları

https://www.britannica.com/place/Najd Erişim Tarihi:23.02.2019

\section{Kaynak Kişiler}

\begin{tabular}{|c|c|c|c|c|}
\hline No & Unvan/Ad/Soyad & $\begin{array}{l}\text { Doğum } \\
\text { Yeri }\end{array}$ & $\begin{array}{l}\text { Doğum } \\
\text { Tarihi }\end{array}$ & Mesleği \\
\hline KK1 & $\begin{array}{l}\text { Prof. Dr. Mustafa } \\
\text { AQUiL AL HATIP }\end{array}$ & Katar & 1945 & $\begin{array}{l}\text { Akademisyen Katar } \\
\text { Üniversitesi - Emekli- } \\
\text { Tarihçi }\end{array}$ \\
\hline KK2 & $\begin{array}{l}\text { Prof. Dr. Ibrahim } \\
\text { SHAHDAD }\end{array}$ & Katar & 1955 & $\begin{array}{l}\text { Akademisyen Katar } \\
\text { Üniversitesi -Tarihçi }\end{array}$ \\
\hline KK3 & $\begin{array}{l}\text { Dr. } \\
\text { HAMAM }\end{array}$ & Misır & 1952 & $\begin{array}{lr}\text { Akademisyen } & \text { Katar } \\
\text { Üniversitesi } & \text {-Tarih } \\
\text { Eğitimi Vakfı Başkanı - } \\
\text { Tarihçi }\end{array}$ \\
\hline KK4 & $\begin{array}{l}\text { Ali Abdullah ibrahim } \\
\text { AL-ENSARi }\end{array}$ & Katar & 1978 & Yazar ve Şair \\
\hline
\end{tabular}

